\title{
RADULY ZSUZSA
}

\section{A közlekedési bűncselekmények mediációja}

Magyarországon 1990 óta évente kevesebb mint harmincezer közlekedési büncselekményt regisztráltak. Kivétel az 1992-es év, amikor a közlekedési büncselekmények száma kiugróan magas, 33130 volt. Azóta a növekvő életszínvonal és a motorizáció fejlődése ellenére a közlekedési bünözés mértéke évröl évre csökken, az évente elkövetett közlekedési büncselekmények száma 1996 és 2006 között húsz- és huszonegyezer között mozgott, míg a legutóbbi években tizenhárom-tizennégyezerre esett vissza. ${ }^{1}$

A Központi Statisztikai Hivatal adatai szerint a 2007-ben jogerősen elítéltek közül minden ötödiket közlekedési büncselekmény elkövetése miatt ítélték el. Különösen nagy azoknak az aránya, akiket ittas jármüvezetés miatt vontak felelősségre, ezt követi a közúti baleset okozása mint második leggyakoribb közlekedési büncselekmény. ${ }^{2}$ Országosan százezer lakosra számítva 209 személyt ítéltek el közlekedési büncselekmény miatt 2007-ben. E büncselekményeket a férfiak jóval gyakrabban követték el, mint a nők. Ugyanebben az évben 5879 ember vált közlekedési büncselekmény sértettjévé. ${ }^{3}$

A közlekedési konfliktusokban az elkövető és az áldozat viszonya véletlenszerü, és az elkövetők - akik legtöbbször az átlagpolgárhoz hasonlítanak - egy pillanatnyi figyelmetlenség, meggondolatlanság miatt sodorják veszélybe a maguk és mások életét és testi épségét.

A balesetiok-kutatás ma már jelentős múltra tekint vissza, az Egyesült Államokban már az első világháború utáni években tanulmányozták a munkahelyi balesetek okait a baleset-megelózés érdekében. ${ }^{4}$ A kriminológiai kutatások nyomán ismerjük a közlekedési balesetek tipikus körülményeit és a közlekedésibün-elkövetők profilját is.

A közlekedésiszabály-sértésekért és a közlekedési balesetek okozásáért felelősségre vontak körében a felsőfokú iskolai végzettségüek alulreprezen-

\footnotetext{
1 A regisztrált büncselekmények és elkövetőik (1990-).

http://www.ksh.hu/docs/hun/xstadat/xstadat eves/i zjb002.html.

2 Szalainé Homola Andrea (szerk.): Az ismertté vált büncselekmények és elkövetőik Magyarországon.

Központi Statisztikai Hivatal, Miskolc, 2008, 15. o.

3 Uo. 29. o.

4 Irk Ferenc: Közlekedés-biztonság és bünözéskontroll. KJK, Budapest, 2003, 48. o.
} 
táltak, míg az alacsonyabb végzettségủek egyre inkább felülreprezentáltak. Irk Ferenc ezt azzal magyarázza, hogy a magasabban kvalifikáltak képesek a közlekedés kívánalmainak leginkább megfelelő magatartást tanúsítani, álláspontja szerint az eltérés nem magyarázható önmagában azzal, hogy a tanultabb emberek jobban tudják érvényesíteni az érdekeiket, mint mások. ${ }^{5} \mathrm{~A}$ balesetezők csoportjának további jellemző vonása, hogy a generációs mobilitás miatt más településen élnek, mint ahol felnőttek, így kevésbé jól ismerik azt a környezetet, amelyben nap mint nap közlekednek. Az iskolai sikertelenség, az, hogy valaki bizonyítványszerzés nélkül fejezett be egy iskolát, szintén a balesetokozás valószínüségét növelö faktor. ${ }^{6} \mathrm{~A}$ balesetokozók közül sokan nem szereztek szakmát, vagy a szakmájuktól eltérö foglalkozást üznek. Minél elégedettebb a munkájával, minél stabilabb az élethelyzete, a volán mögött ülő személy annál biztonságosabban vezet. Hasonló módon befolyásolja a közlekedési magatartást a jó családi légkör, a pozitív munkahelyi hangulat és a szabadidő aktív pihenéssel töltése. ${ }^{7}$ A balesetezők körében magasabb arányban szerepelnek a büntetett előéletüek és a szabálysértés miatt elmarasztaltak. Az ittas gépjárművezetők és a szándékos közlekedési büncselekményeket elkövetők között pedig jelentős arányban vannak olyanok, akik korábban erőszakos büncselekményt követtek el. ${ }^{8}$

Abban, hogy valaki egy közlekedési konfliktus részesévé váljon, a szociológiai tényezőknek van elsődleges szerepük. Irk Ferenc szerint az egyén társadalmi közege az, amely alapvetően determinálja az egyén közlekedésibün-elkövetővé válását. A szociológiai feltételek mellett lényeges szerepe van a közlekedési szituációnak és a közlekedésben részt vevő partnerek viselkedésének is. ${ }^{9}$

Mivel a közlekedési baleset „csak véletlenszerü bizonyítéka” annak, hogy az ember nem képes megfelelni a környezet kihívásainak, a közlekedési büntetőjog eszközeivel nem kényszeríthető ki a hibátlan közlekedési magatartás. Sem a konkrét cselekmény megvalósítójának, sem a társadalom többi tagjának visszatartása érdekében nem lehet cél ,a tökéletes modell” követése. A szerző szerint a közlekedési konfliktusok kezelése annyiban fejlődött az elmúlt évtizedekben, hogy megelőzésük számos módját alkalmazzák, és a következmények kezelésének is több alternatívája ismert. ${ }^{10}$ 
Irk a büncselekményt rövid időn belül követő büntetést tartja hatékony eszköznek a prevenciós célok megvalósítására ${ }^{11}$, míg a közlekedési büntetőjog reformját elsősorban jogdogmatikai úton látja szükségesnek. ${ }^{12}$ Viski Lászlóval egyetértve a közlekedési konfliktusok újfajta kategorizálását sürgeti, elsősorban a generális prevenció érdekében. Felfogása szerint a társadalom nevelése egzakt módon meghatározott szabályok útján valósítható meg, a durva szabályszegések esetén elöre láthatóvá kell tenni a lehetséges következményeket a társadalom tagjai számára. A diverziós eljárások és a sérelem jóvátétele a szerző szerint is hatékony eszköz a speciális prevenció érdekében, ezeket kiegészíthetik a szituációs bünmegelőzési eszközök. ${ }^{13} \mathrm{Ha}$ az elkövetö feltünően gondatlanul vezetett, és ez ismételten fordult elö, a diverzió nem alkalmazható. ${ }^{14}$

Gönczöl Katalin szerint a Magyarországon 2007-ben bevezetett mediáció a hagyományos büntetőeljárást új szemponttal egészítette ki. ${ }^{15} \mathrm{~A}$ helyreállító igazságszolgáltatás filozófiáján alapuló eljárásban a konfliktusban érintett felek egy szakember közremüködésével szembesülhetnek a konfliktushoz vezető okokkal és a következményekkel, majd az elkövető a sértettet kiengesztelve nyugvópontra helyezheti a konfliktust, helyreállítva az áldozatnak és a közösségnek okozott sérelmet. A közvetítői eljárás egyszerre szolgál általános és speciális megelőzési funkciót. A büntetőpolitikai reform nyomán a mediáció a közlekedési, a személy és a vagyon elleni büncselekményekben is elrendelhetö.

\section{A kutatás módszertana}

A kutatásom célja a 2007. január 1. és a 2010. december 31. között a Szabolcs-Szatmár-Bereg megyében elrendelt közvetítői eljárások kriminológiai szempontú vizsgálata volt. A közvetítői eljárásokat az alapul szolgáló büntető ügyiratok és a közvetítöi eljárás során keletkezett iratok vizsgálatával, azaz tartalomelemzés útján tanulmányoztam. ${ }^{16} \mathrm{E}$ vizsgálatban az elemzési egy- 
ség és a megfigyelési egység egybeesett, azok a mediációval érintett egyes terheltek voltak. Egyes kérdéseknél azok jellegéből adódóan az elemzési egység a büncselekmény volt. A mintavételhez használt alapsokaság a Szabolcs-Szatmár-Bereg megyében müködő ügyészségek és bíróságok által elrendelt közvetítői eljárásban szereplő terheltek és a büncselekmények. ${ }^{17}$

A kutatás során a mintavételt részben a valószínüségi szisztematikus mintavétel jellemezte, azaz minden ügy terheltjére és minden büncselekményre igaz volt az a megállapítás, hogy ugyanolyan valószínüséggel kerülhettek be a vizsgált ügyek közé. A mintavételt ez jellemezte a Nyíregyházi Városi Ügyészség által lefolytatott mediációs ügyek vizsgálata során, ahol az érintett terheltek feléről készítettem kérdőívet. A kiválasztás alapját az Igazságügyi Szolgálat (korábban Igazságügyi Hivatal) által átadott ügyféllista adta (mintavételi keret), ezen éves bontásban, az ügyek hivatalhoz érkezésének időbeli sorrendjében szerepeltek a mediációs ügyekben érintett terheltek. Itt minden második terheltet, illetve az ügyét vizsgáltam (szisztematikus mintavétel).

Másrészt a megyeszékhelyen kívüli ügyészségeken lefolytatott mediációról végzett kutatásom teljes mértékben reprezentatív, mivel itt valamennyi ügyet tanulmányoztam, és ugyanez érvényes a bíróságok által elrendelt mediációra is.

A kérdőíves vizsgálat során a kérdőív alapján kódoltam és osztályoztam a megfigyelési egységeket. A kérdőíves vizsgálat folyamán alapvetően a közlések manifeszt, kimondott tartalmát vizsgáltam. Egyes kérdések megválaszolásánál a latens tartalmat is figyelembe vettem a kódoláskor. A kódolás eredménye numerikus volt.

\section{A mediációra utalt közlekedési bűncselekmények}

A mediáció a vizsgálat tárgyául szolgáló időszakban a közlekedési büncselekmények esetében is elrendelhető volt. Az 1978. évi IV. törvény az következő közlekedési büncselekmények esetében tette lehetővé a mediációt: a közlekedés biztonsága elleni büncselekmény (Btk. 184. §); a vasúti, légi vagy vízi közlekedés veszélyeztetése (Btk. 185. §); a közúti veszélyeztetés (Btk. 186. §); a közúti baleset okozása (Btk. 187. §); a járművezetés ittas vagy bódult állapotban (Btk. 188. §); a jármüvezetés tiltott átengedése (Btk. 189. §);

17 Earl Babbie: A társadalomtudományi kutatás gyakorlata. Balassi Kiadó, Budapest, 2008, 744. o. 
és a cserbenhagyás (Btk. 190. §).$^{18} \mathrm{~A}$ Btk. a személy elleni büncselekmények között szabályozta a segítségnyújtás elmulasztásának törvényi tényállását (Btk. 172. §), azonban kriminológiai szempontból ez a büncselekmény jellegénél fogva a közlekedési bünözés része. Emiatt jelen elemzés a segítségnyújtás elmulasztása miatt induló büntetőügyekben elrendelt mediációt a közlekedési ügyekben alkalmazott mediáció keretében vizsgálta.

A mediációra utalható közlekedési büncselekményekre is érvényes volt a Btk. 36. § (3) bekezdésében írt szabály, amely szerint a mediáció nem rendelhetö el, ha a büncselekmény halált okozott, és ha a megvalósult büncselekmény felső (maximális) büntetési tétele súlyosabb, mint ötévi szabadságvesztés. Ezért a mediációt nem lehetett elrendelni - egyebek között - a halált okozó közúti baleset gondatlan okozásának vétsége miatt indult büntetőügyekben, mert ezek a büncselekmények a sértett halálához vezettek, bár a büncselekmény felső büntetési tétele - ötévi szabadságvesztés - még lehetővé tette volna a közvetítői eljárásra utalást [Btk. 187. § (1) bek.; (2) bekezdés b) pont].

A táblázat a Szabolcs-Szatmár-Bereg Megyei Igazságügyi Hivatalhoz mediáció lefolytatása céljából megküldött közlekedési büntetőügyek büncselekményenkénti megoszlását foglalja össze.

A legnagyobb arányban a közúti baleset gondatlan okozásának vétsége miatt indult büntetöügyekben rendelték el a mediációt, de 2008-tól közvetí-

A Szabolcs-Szatmár-Bereg Megyei Igazságügyi Hivatalhoz érkezett és mediációra utalt közlekedési ügyek ${ }^{19}$

\begin{tabular}{|l|c|c|c|c|}
\cline { 2 - 5 } \multicolumn{1}{c|}{} & 2007 & 2008 & 2009 & 2010 \\
\hline közlekedés biztonsága elleni büncselekmény & - & 1 & 1 & 2 \\
közúti baleset gondatlan okozása & 8 & 8 & 27 & 33 \\
közúti veszélyeztetés & - & 1 & 3 & 3 \\
cserbenhagyás & - & 1 & - & - \\
segítségnyújtás elmulasztása & - & - & 1 & 1 \\
összesen & 8 & 11 & 32 & 39 \\
\hline
\end{tabular}

18 A kutatásban vizsgált büntetöügyekre a 2013. június 30-ig hatályos büntető törvénykönyvről szóló 1978. évi IV. törvényt kellett alkalmazni.

19 A közlekedési ügyek esetszámai és megoszlása a Szabolcs-Szatmár-Bereg Megyei Igazságügyi Hivatal által 2011. július 19. napján rendelkezésemre bocsátott adatsorokon alapul. A kutatásban a segítségnyújtás elmulasztása büncselekményt a közlekedési ügyek közé soroltam, mert a büncselekmény kriminológiai szempontból e büncselekménycsoporthoz tartozik, bár a büntető törvénykönyvről szóló 1978. évi IV. törvény e büncselekményt a személy elleni büncselekmények között szabályozza. Az igazságügyi hivatal által vezetett lajstromrendszerben egy ügyhöz egy büncselekménytípus rendelhető hozzá, így a közlekedési ügyek lajtrom szerinti besorolása eltérhet a kutatásban megállapított büncselekmény-kategóriától. 
tői eljárást folytattak közlekedés biztonsága elleni büncselekmény, közúti veszélyeztetés és cserbenhagyás, 2009-től segítségnyújtás elmulasztása miatt induló büntetöügyekben is.

A közúti baleset gondatlan okozásának vétségét az jellemzi, hogy az elkövető szándékosan szegi meg a közúti közlekedés szabályait, és ezzel okozati összefüggésben egy vagy több személynek nyolc napon túli gyógyulási tartamú sérülést okoz. A terhelt szándéka sosem terjed ki arra, hogy a sértetteknek sérülést okozzon, erre csak a gondatlansága terjed ki, azaz könnyelmüen bízik az elöre látott következmények elmaradásában, vagy a szabályszegés következményeit azért nem látja elöre, mert a töle elvárható figyelmet vagy körültekintést elmulasztja. A cselekmény elöidézheti azt, hogy a sértett nyolc napon túl gyógyuló testi sérülést, maradandó fogyatékosságot vagy súlyos egészségromlást szenved el, illetve a büncselekmény következtében tömegszerencsétlenség következik be. A büncselekmény alapesetében a sértett nyolc napon túl gyógyuló sérülést szenved, és e bủncselekmény egy évig terjedő szabadságvesztéssel volt büntetendö. A büncselekmény súlyosabban minősült, és három évig terjedő szabadságvesztéssel volt büntetendő akkor, ha maradandó fogyatékosságot, súlyos egészségromlást vagy tömegszerencsétlenséget okozott.

A közlekedés biztonsága elleni büncselekményt, a vasúti, légi vagy vízi közlekedés veszélyeztetése büncselekményt, a közúti veszélyeztetést, az ittas vagy bódult állapotban elkövetett jármüvezetést, a jármủvezetés tiltott átengedését az jellemzi, hogy az elkövető a biztonságos közlekedést veszélyeztető helyzetet idéz elő. A veszélyhelyzet előidézése, az, hogy az elkövető alkohol, illetve kábítószer hatása alatt vezet, illetve a jármúvezetését olyan személynek engedi át, aki szeszes italtól befolyásolt állapotban van, vagy egyéb okból alkalmatlan a járművezetésre, már önmagában megvalósítja a büncselekményt. E büncselekmények súlyosabban minősültek, ha az elkövető cselekménye nemcsak veszélyhelyzetet idézett elö, hanem legalább nyolc napon túl gyógyuló sérülést okozott, illetve a járművezetés tiltott átengedése esetében legalább maradandó fogyatékosságot okozott. A közlekedés biztonsága elleni büncselekmény, a vasúti, légi vagy vízi közlekedés veszélyeztetése büncselekmény és a közúti veszélyeztetés három évig, míg az ittas vagy bódult állapotban elkövetett járművezetés és a járművezetés tiltott átengedése egy évig terjedő szabadságvesztéssel volt büntetendő.

A cserbenhagyás és a segítségnyújtás elmulasztása esetében az elkövető egy már létrejött veszélyhelyzethez kapcsolódó gondossági, illetve segítségnyújtási kötelezettségét szegi meg. A törvény a segítségnyújtás elmulasztását két, a cserbenhagyást egy évig terjedő szabadságvesztéssel pönalizálta. 
A közúti baleset gondatlan okozásának vétsége esetében rendelték el a legtöbbször a mediációt. A mediált közlekedési ügyek közül 2007-ben 100; 2008-ban 72,7; 2009-ben 84,4; 2010-ben 84,6 százalékban e büncselekmények miatt indult az eljárás.

A mediációt általában olyan büncselekmények esetében rendelték el, amelyek alapesetnek minősülnek, és egy évig terjedő szabadságvesztéssel büntetendők. A bíróság 2008-ban két, 2009-ben egy, majd 2010-ben két olyan ügyet utalt közvetítői eljárásra, amelyben a sértett maradandó fogyatékosságot, súlyos egészségromlást szenvedett el, vagy tettének következményeként tömegszerencsétlenség következett be, és amelynek büntetési tétele három évig terjedő szabadságvesztés volt. 2008-tól már az ügyészi gyakorlat is alkalmazta a mediációt a súlyosabb következménnyel járó büncselekmények miatt induló ügyekben, 2010-ben pedig három ilyen esetben rendeltek el mediációt. A segítségnyújtás elmulasztásának a veszélyhelyzetet előidéző által elkövetett büntette esetében - amely szintén súlyosabban minősül - 2009től alkalmazta a mediációt.

A vizsgált ügyek körében a mediáció alkalmazására leggyakrabban az egyévi szabadságvesztéssel büntetendö büncselekmények esetében került sor, míg a háromévi szabadságvesztéssel büntetendö büncselekmények esetén ritkábban rendelték el a közvetitöi eljárást. A törvényi lehetöség ellenére a mediáció alkalmazása nem vált elterjedtté az ittas vagy bódult állapotban elkövetett jármüvezetés esetében, és azoknál a büncselekményeknél sem, amelyeknél a büntetési tétel felső határa ötévi szabadságvesztés. Mind az ügyészi, mind a birói gyakorlat elsösorban a legenyhébb büntetéssel fenyegetett és kevésbé súlyos eredménnyel járó büncselekmények esetében alkalmazta ezt a diverziós eszközt.

\section{A mediáció elrendelése a közlekedési ügyekben}

2007 és 2010 között a megyeszékhelyi ügyészségek és bíróságok kizárólagos illetékességgel jártak el a közlekedési büntetőügyekben.

$\mathrm{Az}$ 1. számú ábra azt mutatja be, a mediáció elrendelése hogyan oszlott meg az ügyészség és a bíróság között a közlekedési ügyekben.

Látható, hogy a közvetítői eljárás alkalmazásának gyakorisága összességében évről évre nőtt. A mediáció bevezetésekor a bíróság többször rendelt el közvetítői eljárást, mint az ügyészség. Míg az ügyészség által elrendelt közvetítöi eljárások száma az évek folyamán következetesen növekedett, a bíró- 


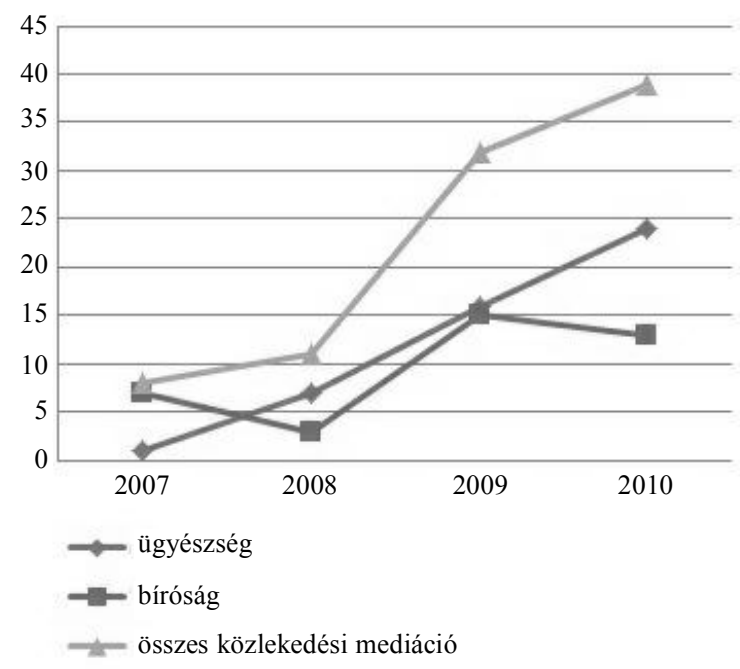

ság által elrendelt mediáció száma 2008-ban csökkent, 2009-ben nőtt, majd 2010-ben ismét csökkent az előző évhez képest.

Az ügyészség által elrendelt mediáció esetében az ügyeket az jellemezte, hogy a rendőrség a kihallgatáskor szinte kivétel nélkül tájékoztatta a gyanúsítottat a közvetítői eljárásról, azonban a sértett 2007 és 2009 között egyáltalán nem kapott felvilágosítást arról, hogy közvetítői eljárást kezdeményezhet. Még 2010-ben is csupán a sértettek 14,3 százaléka kapott erről szóló tájékoztatást. Azonban ezekben az ügyekben a közvetítöi eljárásra mégis sor került. A vizsgált ügyekben a nyomozás befejezése után az ügyész meghallgatta a gyanúsítottat és a sértettet, 2007 és 2010 között ugyanis az eljárási törvény kötelezővé tette az ügyész számára a gyanúsított és a sértett meghallgatását a közvetítői eljárás feltételeinek, a terhelt teljesítési készségének és képességének, a hozzájárulás önkéntességének vizsgálata céljából. ${ }^{20}$ Ennélfogva ezekben az esetekben az ügyész tájékoztatta az elkövetőt és a sértettet a mediációról. A gyanúsított mellett védő ritkán vett részt az eljárásban, és a védő ritkán (2009-ben egy ügyben) tájékoztatta védencét a mediáció alkalmazásának lehetőségéről.

A bíróság által közvetítői eljárásra utalt ügyekben a rendőrség a nyomozás során többnyire szintén tájékoztatta a gyanúsítottat arról, hogy közvetítői

20 A büntetőeljárásról szóló 1998 . évi XIX. törvény 224. § (4) bekezdés. 
eljárást kezdeményezhet, bár a mediáció bevezetésének évében ez csupán a bíróság által mediációra utalt ügyek felére volt igaz. A többi esetben (2007ben az ügyek felénél, 2008-ban és 2009-ben az ügyek harmadában, 2010-ben az ügyek 16,67 százalékában) a gyanúsított a védőtől kapott felvilágosítást. 2008-ban és 2010-ben egy-egy esetre volt jellemző, hogy a gyanúsított már a konfliktus előtt hallott a mediáció jogintézményéről. Azokban az esetekben, amelyekben védő nem vett részt az eljárásban, megfigyelhető, hogy a bíróság a tárgyaláson tájékoztatta a feleket a közvetítői eljárás alkalmazásának lehetőségéről (2007-ben az ügyek felénél, 2008-ban az ügyek harmadában, 2009ben az ügyek huszonegy százalékában és 2010-ben az ügyek negyedében). A rendelkezésre álló iratok szerint az ügyészség ezekben az ügyekben nem tartott olyan meghallgatást a feleknek, amelyen a közvetítői eljárás feltételeit vizsgálta volna, 2010-ben azonban két ügyben tájékoztatta az elkövetöt a mediációról. 2007-ben a sértett tájékoztatására a nyomozás során elvétve került sor, azonban a bírósági tárgyaláson nyújtott felvilágosítás pótolta ezt. 2008 és 2010 között a rendőrség már többnyire a sértettet is tájékoztatta a mediációról. A bíróság által közvetítői eljárásra utalt ügyekben nagy jelentösége volt annak, hogy a felek a védőtől, illetve a bíróságtól megkapták a mediációról szóló tájékoztatást.

Az ügyészség által közvetítői eljárásra utalt közlekedési büncselekmények esetében a mediáció többnyire a gyanúsított és a sértett közös kezdeményezésére indult, és ennek a közös kezdeményezésnek az ügyészi meghallgatás adott keretet. A sértettnek az eljárás korábbi fázisában nem volt tudomása arról, hogy a jogsértés következményeinek megválasztásában aktív szerepe lehet, az ügyészi meghallgatáson szerzett információk birtokában azonban már - a gyanúsítottal együtt - kérte a mediáció alkalmazását. Ritkábban fordult elő az, hogy kizárólag az elkövető kezdeményezte a mediáció elrendelését, és a sértett ehhez csupán hozzájárult. Az ügyész esetről esetre mérlegelte azt, hogy mely ügyekben tart meghallgatást a közvetítői eljárás feltételeinek vizsgálata érdekében. Kevésbé volt jellemző, hogy az ügyész hivatalból - a felek hozzájárulásának beszerzése után - olyan esetekben rendelte el a mediációt, amelyekben nem állt a rendelkezésére információ a gyanúsított és a sértett előzetes megbékéléséröl. A gyanúsított sok esetben már a nyomozás idején kifejezte azt a szándékát, hogy ha mód van rá, akkor jóvátenné a bűncselekménnyel okozott sérelmet. Az ügyészt a közvetítöi eljárás feltételeinek vizsgálatát célzó meghallgatás megtartásában befolyásolhatta az, ha az elkövető már a rendőrségen úgy nyilatkozott, hogy a sértettől bocsánatot kért vagy a sértettel már kibékült. A sértett önállóan egyetlen eset- 
ben sem kezdeményezett mediációt. 2009-ben két ügyben, 2010-ben egy ügyben a védő kezdeményezte az ügy közvetítői eljárásra utalását.

A bíróság által közvetítői eljárásra utalt ügyekben 2007-ben leggyakrabban az elkövető és a sértett, majd 2008 és 2010 között az elkövető és a védő kezdeményezte az ügy elterelését a bírósági útról. 2009 és 2010 között az ügyek kevesebb mint felében az elkövető a sértettel közösen kezdeményezte a mediációt.

A közvetítői eljárást elrendelő bírói döntésekkel az ügyészség több esetben nem értett egyet, azokkal szemben fellebbezést jelentett be. Az ügyészség több esetben azt a bírói mérlegelést támadta, amelyben a bíró az ügy körülményeit akként értékelte, hogy a büncselekmény jellegére és a terhelt személyére tekintettel a bírósági eljárás lefolytatása mellőzhető.

Egy közúti baleset gondatlan okozása miatt induló eljárásban a bíróság közvetítői eljárásra utalta az ügyet. A közvetítői eljárás elrendelése ellen az ügyész jelentett be fellebbezést, ebben arra hivatkozott, hogy a terhelttel szemben a bírósági eljárás lefolytatása azért nem mellőzhető, mert vele szemben a jármüvezetéstől eltiltást alkalmazni kell. A megyei bíróság azonban helybenhagyta a mediációt elrendelő bírói döntést, és azt állapította meg, hogy a közvetítés mérlegelést igénylö törvényi feltételei fennálltak a konkrét ügyben. A mediáció során a sértett elfogadta a terhelt bocsánatkérését, és a terhelt kilencvenötezer forint fájdalomdijat fizetett a sértettnek ${ }^{21}$.

Szintén közúti baleset gondatlan okozása miatt indult az az eljárás, amelyben az ügyész azért fellebbezett a közvetítöi eljárásra utalás ellen, mert az ügyészség az ügyet egyszer már közvetítői eljárásra utalta, és az nem vezetett eredményre. Ebben az esetben a megyei bíróság az ügyészi fellebbezésnek helyt adott. Döntésében a megyei bíróság a Legfelsőbb Bíróság 3/2007. számú kollégiumi véleményére hivatkozott, és az ott kifejtett jogértelmezést követve adott helyt az ügyészi indítványnak. Végül a bíróság az elkövetőt hetvenötezer forint pénzbüntetésre ítélte ${ }^{22}$.

A közlekedési ügyekben a gyanúsított általában már a nyomozás során tudomást szerzett a mediáció kérelmezésének lehetőségéről, míg a sértett ezen eljárási szakaszban kevésbé gyakran kapta meg a szükséges felvilágosítást. A rendőrség a legutóbbi években a sértettet egyre gyakrabban tájékoztatta. Fon-

21 Nyíregyházi Városi Bíróság B.1984/2006.; Szabolcs-Szatmár-Bereg Megyei Bíróság 3.Bkf.162/2007. 22 Nyíregyházi Városi Bíróság B.1357/2009.; Szabolcs-Szatmár-Bereg Megyei Bíróság 3.Bkf.611/2009. 
tos megjegyezni, hogy ha a jegyzőkönyvek tartalmazták is a mediációról szóló tájékoztatást, a kutatás módszertani korlátai miatt akkor sem tudhatjuk pontosan, hogy a felvilágosítás ténylegesen mire terjedt ki. A sértettek tájékoztatásának gyakran teljes elmaradása jelzi, hogy a mediáció mint jogintézmény áldozatvédelmi célja a joggyakorlat számára nem volt egyértelmű. A közvetítői eljárás sok esetben inkább a terheltet megillető eljárási lehetőségként, mintsem az áldozatok érdekeinek érvényesítését célzó diverziós formaként jelent meg a joggyakorlatban.

A vizsgált ügyekre kevésbé volt jellemző, hogy az eljárás nyomozati szakaszában védő vett részt az eljárásban, azonban a védő részvétele - föként a bíróság előtti eljárásban - támogatóan hatott a mediáció kezdeményezésére.

A bíróság által közvetítői eljárásra utalt ügyekben az ügyész előzetesen nem tartott meghallgatást a közvetítői eljárás feltételeinek vizsgálata érdekében. Az ügyészség a mediációról sem az elkövetőknek, sem a sértetteknek nem nyújtott tájékoztatást 2007 és 2009 között, 2010-ben is csupán két esetben adott felvilágosítást. A törvényi szabályozás kizárólag az ügyész számára teszi lehetővé azt, hogy hivatalból közvetítői eljárásra utalja az ügyet, ha ehhez a felek hozzájárulnak. Ez minden esetben a mediáció feltételeinek vizsgálatát és mérlegelést igényel az ügyész részéről. Az ügyész a bíróság mediációt elrendelő döntéseit több esetben fellebbezéssel támadta, külön figyelmet érdemel, hogy a fellebbezés tárgya több esetben a bírói mérlegelés volt. A vádhatóság az eljárások során arra törekedett, hogy saját mérlegelési szempontjai érvényesüljenek a felek igényeivel és a bíróság mérlegelésével szemben. A felek szándéka, miszerint a konfliktusukat mediációval kívánják rendezni, bizonyos esetekben azért nem érvényesülhetett, mert az ügyészség szerint a büntetés kiszabása nem volt mellőzhető.

A bíróság a vizsgált közlekedési ügyeket - amelyekben az ügyész az elterelés helyett vádat emelt - a mediációra alkalmasnak találta. Ezen ügyekben főként a védői kezdeményezésnek és az eljáró bíró által nyújtott tájékoztatásnak volt döntő szerepe az ügy közvetítői eljárásra utalásában. A sértetteket sok esetben kizárólag a bíró tájékoztatta a mediációról. Bár a törvényi szabályozás kizárólag az ügyész számára teszi lehetővé azt, hogy hivatalból közvetítői eljárásra utalja az ügyet (a felek hozzájárulása után), a gyakorlatban azonban ezekben az esetekben a bíróság vállalt aktív szerepet az elterelésben. A Be. szabályai alapján a bíróság a közvetítői eljárásról köteles tájékoztatni a feleket, de hivatalból nem utalhatja mediációra az ügyet. Legalább a felek valamelyikének vagy a védőnek kifejezetten kérelmeznie kell a közvetítői eljárást, a kérelmet a tárgyaláson jelen lévő felek esetén a bíró jegyzőkönyvbe 
foglalja. A bírói aktivitás azonban a közlekedési ügyek elterelésében nem volt következetes, mert a bíróság által mediációra utalt ügyek száma a korábbi évekhez képest 2008-ban és 2010-ben is csökkent. A bíró aktivitását az áldozatvédelmi szempontok érvényesítésében befolyásolhatta az is, hogy az elterelésről hozott döntéseket az ügyész több esetben megfellebbezte.

\section{A mediációban érintett terheltek jellemzői}

Az ügyészség által közvetítői eljárásra utalt közlekedési büncselekmények elkövetői többnyire olyan huszonnégy évesnél idösebb férfiak voltak, akik érettségit és szakmát szereztek, azonban elvétve előfordult évente egy-két felsőfokú végzettségü elkövető is. Az elkövetők között 2008-ban három, 2010-ben tizenegy nö volt. 2009-ben egy közlekedési büncselekmény elkövetöje egy tizenhat éves fiatalkorú elkövető volt, míg valamennyi vizsgált évben előfordultak tizennyolc és huszonkét év közötti elkövetők (évente egy-két ügyben), 2009-ben és 2010-ben huszonkét és huszonnégy év közötti elkövetők is részt vettek mediációban. Elenyészően, 2009-ben és 2010-ben pedig egyáltalán nem találunk olyan elkövetőket, akiknek a legmagasabb iskolai végzettségük nyolc általános iskolai osztály vagy ennél kevesebb.

Hasonló sajátosságok jellemzik a bíróság által közvetítői eljárásra utalt közlekedési ügyek terheltjeit. Az elkövetők többnyire szintén huszonnégy évesnél idősebb férfiak, évente egy-két ügyben találunk tizennyolc és huszonkét év közötti, huszonkét és huszonnégy év közötti és nő elkövetőket. A vizsgált időszakban évente egy-egy esetben jellemezte az elkövetőt, hogy a legmagasabb iskolai végzettsége az általános iskola nyolc osztálya. Ennél jellemzőbb, hogy felsőfokú végzettségúek, illetve hogy felsőfokú tanulmányokat folytatnak. Az elkövetők többsége azonban - hasonlóan az ügyészi szakban elrendelt mediáció terheltjeihez - olyan személy volt, akinek érettségije, illetve szakmája volt.

A 2. számú ábra a munka és jövedelem nélküli elkövetők ügyeiben elrendelt mediáció megoszlását mutatja be az elrendelő szervek szerint az összes közlekedési ügyben elrendelt mediációhoz képest.

Az ügyészség által mediációra utalt büncselekmények elkövetőinek többnyire rendszeres jövedelmük, nyugdíjuk volt (2009-ben a legtipikusabb a hatvanezer forint alatti és a hatvan- és hetvenezer forint közötti, míg 2010-ben a hetven- és százezer forint közötti és a százezer forint feletti havi jövedelemmel bíró elkövetői csoport). Összességében a rendszeres jövedelmet húzók je- 


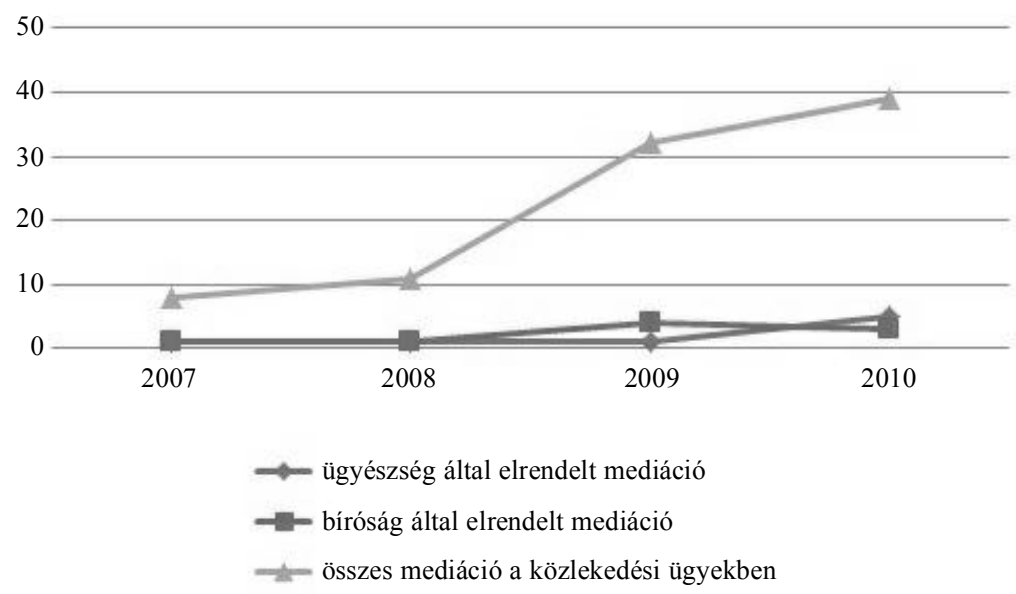

lentősen gyakrabban vették részt az ügyészség által elrendelt mediációban, mint a munka és jövedelem nélküli és szociális ellátásban nem részesülő elkövetők, de 2010-ben ezen elkövetők száma nőtt. A mediációban részt vevő elkövetőket tehát kedvező vagyoni viszonyok jellemezték. 2008-ban, 2009-ben és 2010-ben az érintett terhelteknek általában gépjármüvük és lakóingatlanuk volt, míg vagyontalan elkövetők kivételesen vettek részt a mediációban.

A bíróság által elrendelt közvetítői eljárások elkövetőinek jövedelmi-vagyoni viszonyait hasonló sajátosságok jellemzik. A terheltek többsége rendszeresen kapott munkabért, 2007-ben többnyire a százezer forint feletti, 2009-ben leggyakrabban a hatvan- és hetvenezer forint közötti jövedelmü, 2010-ben a hetven- és százezer forint közötti vagy a százezer forint feletti havi jövedelemmel bíró elkövetők fordultak elö. Az érintett elkövetői csoporton belül már 2007-től találunk munka és jövedelem nélkülieket, akiknek a száma 2009-ben és 2010-ben nőtt. Az elkövetői csoportban az ügyészség által elrendelt mediációban érintett terheltekhez képest nagyobb a vagyontalan elkövetők aránya (3. számú ábra).

Az előbbi adatok alapján megállapítható, hogy a közlekedési ügyekben a mediációt általában a rendszeres jövedelemmel, munkabérrel bíró elkövetök ügyeiben rendelték el, míg a munka nélküli, szociális ellátásban részesülő elkövetők és azok, akiknek nem volt jövedelmük, jóval kisebb arányban vettek részt mediációban. Az elkövetők vagyoni helyzete és a mediációban való részvételük között ugyanez az összefüggés állapítható meg. Minél kedvezőt- 


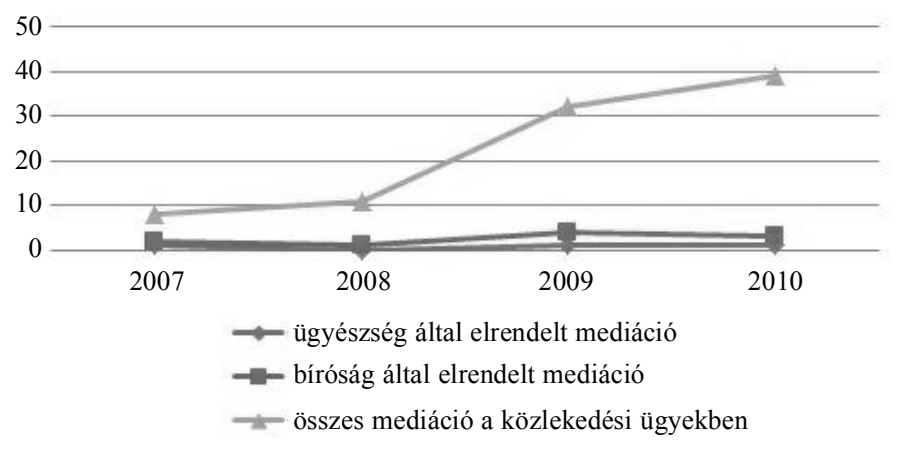

lenebb az elkövető vagyoni helyzete, annál kisebb a valószínüsége annak, hogy akár az ügyészség, akár a bíróság közvetítői eljárásra utalja az ügyet. A bírói gyakorlat azonban az ügyészi gyakorlathoz képest nagyobb arányban utalta közvetítői eljárásra a vagyontalan elkövetök ügyeit. Különösen igaz ez a megállapitás a 2009-es év ügyeire.

\section{A közvetítői eljárásban érintett sértettek jellemzői}

A konfliktusokban érintett sértettekről a terheltekhez képest kevesebb információ állt rendelkezésre az ügyiratokban. Csupán a mediációban részt vevő sértettek nemével, életkorával kapcsolatos kérdéseinkre kaphattunk választ, valamint arra, hogy ügyvéd képviselte-e a sértettet a büntetőeljárásban.

A nemek szerinti megoszlást tekintve a sértettek között 2007-ben és 2008ban a nők voltak többségben, majd 2009-ben és 2010-ben már a férfiak. A sértettek többnyire huszonnégy évesnél idősebbek voltak, kivételesen fordult elö a sértettek között tizennégy év alatti, tizennyolc és huszonkét és huszonkét és huszonnégy év közötti személy. A sértettek érdekében általában nem járt el ügyvéd, 2008-ban azonban az ügyek több mint harmadát jellemezte az, hogy a sértett jogi képviseletet vett igénybe.

A bíróság által közvetítői eljárásra utalt ügyekben 2007-ben fele-fele arányban oszlottak meg a sértettek nemek szerint, majd 2008-ban és 2009ben a sértettek többsége férfi, 2010-ben a sértettek többsége nő volt. A sértettek általában huszonnégy évesnél idősebb felnőttek voltak, 2007-ben egy sér- 
tett fiatalkorú és három sértett gyermekkorú volt. 2009-ben a sértettek sorában tizennyolc és huszonkét és huszonkét és huszonnégy év közöttiek is elöfordultak. A bíróság által mediációra utalt közlekedési ügyek kevesebb mint felében a sértettet ügyvéd képviselte valamennyi vizsgált évben.

Az előbbiekből megállapítható, hogy a bíróság által közvetítői eljárásra utalt ügyeket nagyobb arányban jellemezte az, hogy a sértett jogi képviselőt hatalmazott meg a képviseletére, mint az ügyész által mediációra utalt ügyeket. A sértett jogi képviselete hozzájárult ahhoz, hogy az áldozatok a mediációról megfelelő információhoz jussanak, és a jogi képviselőnek szerepe lehetett az ügyek közvetítői eljárásra utalásának kezdeményezésében is az eljárás bírósági szakaszában.

\section{A konfliktusok jellemzői}

A közvetítöi eljárásban rendezett konfliktusokban többnyire egy sértett és egy elkövető volt érintett. Az ügyészség által közvetítöi eljárásra utalt ügyek közül 2009-ben találunk egy olyan ügyet, amelyben a mediációban két elkövető vett részt, míg a bíróság által közvetítöi eljárásra utalt ügyek között szintén - 2009-ben - két olyan esettel találkozunk, amelyben nem egy, hanem két elkövető volt érintett. Önmagában az, hogy egy bủncselekményt többen követtek el, nem jelenti azt, hogy valamennyi elkövető részt vett a mediációban. Előfordultak olyan esetek, amikor a többek által elkövetett közlekedési bűncselekménynek csak az egyik elkövetöje vett részt a mediációban.

Egy közúti baleset gondatlan okozása miatt indult ügyben csupán az egyik vádlott vett részt a mediációban, míg a másik vádlott nem járult hozzá a közvetítői eljáráshoz. A bíróság az utóbbi elkövetővel szemben egy év, végrehajtásában két év próbaidőre felfüggesztett fogházbüntetést szabott ki, és két évre eltiltotta a közúti járművezetéstől, míg a másik elkövetővel szemben az eredményes mediáció alapján megszüntették az eljárást ${ }^{23}$.

Az ügyészség által mediációra terelt ügyek közül 2008-ban két ügyben fordult elő, hogy a cselekménynek több sértettje volt. A bíróság által közvetítői eljárásra utalt ügyek közül 2007-ben két, 2009-ben egy, 2010-ben két ügyben fordult elő, hogy a sértettek száma kettő vagy három volt. Hasonlóan a töb-

23 Nyíregyházi Városi Bíróság B.259/2009. 
bek által elkövetett cselekményekhez előfordulhat az is, hogy nem vesz részt a mediációban a büncselekmény valamennyi sértettje. A mediáció céljainak megvalósulását azonban az szolgálná, ha a közvetítői eljárásokban, a konfliktusfeloldásban minden érintett részt venne. A konfliktus „feldarabolása” esetén a helyreállító igazságszolgáltatás filozófiája csak részben valósulhat meg.

A mediációs üléseken a feleken kívüli egyéb személyek részvétele általában nem volt jellemző. A gyermek- vagy fiatalkorú sértettek törvényes képviselői és a fiatalkorú elkövető törvényes képviselője vett részt egy-egy esetben a megbeszélésen.

A mediációval érintett konfliktusok túlnyomórészt szituatív módon alakultak ki, és mind az ügyészi, mind a bírói gyakorlatban elterelt ügyek esetében kivételesen fordult elö, hogy az elkövetö és a sértett haragos viszonyban állt egymással (ez 2008-ban, 2009-ben és 2010-ben csupán egy-egy ügyet jellemzett). A konfliktusok további jellemzője, hogy azok „kihült” konfliktusok voltak, de 2009-ben és 2010-ben a mediátor strukturális konfliktusokban is közvetített.

\begin{abstract}
A közúti veszélyeztetés miatt induló eljárásban a felek közötti konfliktus egy közös hölgyismeröshöz kapcsolódott, aki a mediációs ülésen nem vett részt. A konfliktus további érdekessége, hogy a bíróság a közúti veszélyeztetés miatt induló eljárást egyesítette egy másik üggyel, amelyben a jelen ügy terheltje volt a sértett, míg a jelen ügy sértettje a terhelt. Bár a felek közötti konfliktust erősen átszőtték a közös hölgyismerőshöz füződő érzelmek, és a felek a két büntetőügyben „fordított szerepben" tüntek fel, a mediáció keretében megkötött megállapodás tartalmát ez nem befolyásolta. A terhelt harmincötezer forint fájdalomdíj megfizetésére tett ígéretet, amit elsősorban a biztosító közremüködésével kívánt megtéríteni ${ }^{24}$.
\end{abstract}

Az ügyészség által elterelt ügyekben az elkövetők és a sértettek konfliktust megelőző kapcsolatára általában az volt jellemző, hogy a konfliktusban érintett felek korábban nem ismerték egymást. 2008-ban az ügyek felében, 2009ben az ügyek több mint kétharmadában és 2009-ben az ügyek közel nyolcvan százalékában az elkövető és a sértett a konfliktus előtt egyszer sem találkozott egymással. A 2007-ben lefolytatott egyetlen mediációs eljárásban a konfliktusban érintett felek egymás távoli rokonai voltak és ugyanazon a településen éltek, 2008-ban az ügyek harmadában testvérek és távoli rokonok voltak. 2009-ben és 2010-ben egyetlen elkövetőt és sértettet sem füzött egy-

24 Nyíregyházi Városi Bíróság B.712/2010. 
máshoz rokoni kapcsolat. 2008-ban, 2009-ben és 2010-ben az ügyek kis hányadában munkatársak, ismerősök voltak a konfliktusban érintettek. 2007ben, 2008-ban és 2009-ben egyetlen olyan eset sem fordult elö, amelyben a konfliktusban érintett felek egymás szomszédjai vagy barátai voltak. 2010ben azonban a szomszédi viszony és a baráti kapcsolat kis arányban jellemző volt. 2008-ban, 2009-ben és 2010-ben nem volt számottevő az eltérés aszerint, hogy az elkövetők és a sértettek ugyanazon a településen vagy másmás településen éltek.

A bíróság által elterelt ügyek többségében a sértett és az elkövető korábban szintén nem ismerte egymást. A fennmaradó ügyeket közel azonos arányban jellemezte az, hogy az elkövetőt és a sértettet rokoni kapcsolat, baráti vagy ismerősi viszony füzte egymáshoz. A felek a 2007-ben és a 2008-ban mediált ügyek közel felében azonos településen éltek, 2009-ben és 2010-ben többnyire ugyanazon a településen éltek.

\begin{abstract}
A Nyíregyházi Városi Bíróságon eljárás folyt közúti baleset gondatlan okozása miatt. A balesetet okozó elkövetöt és a sértettet rokoni kapcsolat füzte egymáshoz, ugyanis az elkövető a sértett gyermeke volt. A sértett a balesetben nyolc napon túl gyógyuló sérülést szenvedett, míg a terhelt a baleset következtében mozgássérültté vált. A cselekmény elkövetési ideje (2005. június 4.) és az eljárás megszüntetése között hosszú idő telt el, erre ugyanis az eredményes mediáció nyomán 2009 szeptemberében került sor. A közvetítői eljárást ebben az esetben védői indítványra a bíróság rendelte el. ${ }^{25}$
\end{abstract}

A rendelkezésre álló iratokból megállapítható, hogy a konfliktusok az ügyészség által közvetítői eljárásra utalt ügyekben részben már a mediációs ülés előtt rendeződtek. 2009-ben és 2010-ben már növekedett azon esetek száma, amelyeknél a közlekedési bủncselekménnyel kiváltott konfliktus a mediáció keretében került nyugvópontra. A mediáció alkalmazása a mediációs ülés elött már részben rendeződött konfliktusok esetében is célszerủ volt, mert ez tette lehetővé a konfliktus okainak részletes feltárását, és a konfliktusok végleges lezárását a szakember közremüködésével. A bíróság által közvetítői eljárásra utalt ügyekben a konfliktusok többsége elsősorban a mediáció keretében rendeződött, a mediáció tárta fel a konfliktus okait, és kevesebb volt azon esetek száma, amikor a közvetítői eljárásra utalt konfliktusok már a mediációs megbeszélés előtt nyugvópontra kerültek.

25 Nyíregyházi Városi Bíróság B.259/2009. 
A bíróság által közvetítői eljárásra utalt ügyekben a mediáció nagyobb arányban töltötte be a konfliktusrendező funkcióját, mint az ügyészség által közvetítői eljárásra utalt ügyekben.

\section{A megállapodások jellemzői}

A felek a közvetítői eljárásban a legtöbb esetben megállapodást kötöttek egymással az ügyész elterelésröl hozott döntése után. 2008-ban az ügyek hatodában, 2009-ben az ügyek ötödében, 2010-ben az ügyek nyolcadában nem jött létre megállapodás a felek között. Ezekben az ügyekben a mediáció azért nem vezetett eredményre, mert a felek nem tudtak mindkét fél számára megnyugtató módon megállapodni a jóvátételről. 2009-ben egy ügyben a sértett visszavonta a mediációhoz nyújtott hozzájárulását, emiatt a közvetítői eljárást nem lehetett eredményesen lezárni.

A biróság által közvetitöi eljárásra utalt ügyekben a megállapodások arányát nagyobb változatosság jellemezte. 2007-ben a közvetítői eljárásra utalt ügyekben a megállapodást minden esetben sikerült megkötni, míg 2008ban az elrendelt kevés mediáció egyikében sem született megállapodás. 2009-ben az ügyek harmadában, 2010-ben pedig az ügyek hatodában nem jött létre megállapodás a felek között. 2008-ban a megállapodások megkötésére többnyire amiatt nem került sor, mert a sértett nem ment el a mediációs megbeszélésre, így a közvetítôi eljáráshoz adott hozzájárulását visszavontnak kellett tekinteni. Míg egy másik esetben a sértett visszavonta a közvetítői eljárás lefolytatásához adott hozzájárulását. 2008-ban és 2009-ben egy esetben a közvetítői eljárásra utalásról szóló elsőfokú bírósági határozat hatályon kívül helyezésére került sor. 2009-ben a felek négy esetben nem tudtak megállapodni a mindkét fél számára megfelelő jóvátételről, illetve egy-egy esetben az elkövető, illetve a sértett visszavonta a közvetítői eljáráshoz adott hozzájárulását. 2010-ben a megállapodások megkötésének azonos arányban volt akadálya az, hogy a felek nem tudtak megállapodni egymással és az, hogy a sértett, illetve az elkövető visszavonta a hozzájárulását.

A közvetítői eljárásban az esetek többségében a felek már az első mediációs ülésen megkötötték a megállapodást. 2009-ben és 2010-ben egy-egy ügyben fordult elő, hogy két-három mediációs ülést tartottak az ügyben.

A Nyíregyházi Városi Ügyészségen folyamatban lévő ügyben a közúti balesetet egy fiatalkorú okozta, míg a cselekmény áldozatai tizennégy éven 
aluliak voltak. Bár a mediátor két ülést tartott az ügyben, megállapodás mégsem született a felek között. ${ }^{26}$

Az ügyészi szakban elrendelt közvetítöi eljárások megállapodásait tekintve megállapítható, kevéssé jellemző az, hogy a konfliktust puszta bocsánatkéréssel zárták le a felek. A 2007-ben lefolytatott mediációs ügyet és a 2008-ban lefolytatott öt mediációs ügy egyikét jellemezte e jóvátételi forma. A mediációs megállapodásokat általában a bocsánatkérés mellett nyújtott pénzbeli jóvátétel jellemezte 2008-ban, 2009-ben és 2010-ben, míg a bocsánatkérés mellett nyújtott pénzbeli és nem pénzbeli jóvátételi forma általában kevésbé volt jellemző, 2009-ben a megkötött megállapodások negyedét jellemezte. A jóvátétel valamennyi esetben a sértett javára szolgált. Egyetlen olyan eset sem fordult elö, amelyben a jóvátétel címzettje a megsértett közösség lett volna, és olyan sem, amelyben a nem pénzbeli jóvátétel formája összefüggött volna az elkövető szakértelmével.

A bíróság által elrendelt mediáció esetében a megkötött megállapodásokat általában nem jellemezte az, hogy a felek a konfliktust bocsánatkéréssel zárták le. Azonban 2009-ben a megállapodások ötödében az elkövető a bocsánatkérésen kívül nem nyújtott más jóvátételt.

Az igazságügyi hivatal közvetítői eljárást folytatott le egy olyan közlekedési baleset miatt induló eljárásban, amiben a büncselekmény sértettje az elkövető édesanyja volt. A bíróság eredményesnek ítélte a mediációt, amelynek keretében az elkövető felelősséget vállalt a cselekményért, és bocsánatot kért a sértettől. Az ügyészség azonban fellebbezést jelentett be az eljárás megszüntetése ellen, mert álláspontja szerint az elkövetőnek a sértettet olyan helyzetbe kellett volna hoznia a mediáció keretében, mintha a baleset be sem következett volna, és ehhez - álláspontja szerint - nem elég a bocsánatkérés. A megyei föügyészség azonban ezt a fellebbezést visszavonta, így az eljárást megszüntették ${ }^{27}$.

Az eredményes mediációk esetében leginkább a jóvátételnek az a formája terjedt el, amelynek keretében az elkövető bocsánatot kért a sértettől, és emellett pénzbeli jóvátételt is nyújtott.

A maradandó fogyatékosságot okozó közúti baleset miatt induló ügyben a terhelt jóvátételként százezer forint összegben a mütéti kiadásokat, száznegyvenkétezer

\footnotetext{
26 Nyíregyházi Városi Ügyészség Fk.6419/2009.

27 Nyíregyházi Városi Bíróság B.1548/2007.; Szabolcs-Szatmár-Bereg Megyei Főügyészség Bf.227/2008.
} 
forint összegben a fogorvosi költségeket térítette meg a sértettnek, és harmincezer forint összegü fájdalomdíjat fizetett neki ${ }^{28}$.

A közlekedési ügyek sajátossága, hogy az elkövetök egyes esetekben a mediációt követően a biztosító közremüködésével térítik meg a cselekménynyel okozott vagyoni károkat, míg a mediáció keretében úgynevezett fájdalomdíj fizetését vállalják. Így a konfliktuslezárás sok esetben nem végleges, hiszen a biztosító döntése még kihatással lehet a felek kapcsolatára, ennélfogva befolyásolhatja az elkövető reintegrációját is.

A terhelt a közúti baleset miatt induló ügyben megkötött megállapodásban elismerte a felelösségét a történtek miatt, és százötvenezer forint fájdalomdíj megfizetését vállalta. Az elkövető ígéretet tett arra, hogy minden, a jövőben felmerülö kárt a biztosító segítségével rendezni fog. A megállapodás rögzítette, hogy a jóvátétel összege nem számít bele a biztosító által fizetendő összegbe. ${ }^{29}$

A bocsánatkérés mellett nyújtott pénzbeli és nem pénzbeli jóvátétel jellemezte a 2007-ben megkötött megállapodások 14,28, a 2010-ben megkötött megállapodások 20 százalékát. A jóvátétel valamennyi esetben a sértett javát szolgálta. A nem pénzbeli jóvátételi forma az elkövető foglalkozásával, szakértelmével egyik esetben sem volt kapcsolatban.

A Nyíregyházi Városi Bíróságon folyamatban lévő ügyben a terhelt háromszázötvenezer forint pénzbeli jóvátétel nyújtása mellett azt vállalta, hogy a védője segíteni fog a sértettnek a biztosítóval kapcsolatos kárügyintézésben. ${ }^{30}$

Az ügyész által elrendelt diverzió esetében a megállapodás teljesítési határidejét tekintve megállapíthatjuk, hogy az elkövetők általában már a mediációs ülésen teljesítették a megállapodásokat mind a négy vizsgált évben. 2009-ben és 2010-ben már előfordult néhány ügyben, hogy az elkövetők egy és négy hónap között tettek eleget a vállalt kötelezettségüknek. ${ }^{31} \mathrm{~A}$ megállapodásokat valamennyi ügyben betartották. Az ügyészség a közvetítői eljárá-

\footnotetext{
28 Nyíregyházi Városi Bíróság B.1484/2009.

29 Nyíregyházi Városi Bíróság B.1121/2010.

30 Nyíregyházi Városi Bíróság B.1203/2010.

31 A megállapodás teljesítésének határideje 2009-ben egy esetben egy hónap, egy esetben három hónap volt, míg 2010-ben két esetben egy, egy esetben három, egy esetben négy hónapos teljesítési határidőt vállalt.
} 
sok eredményességét általában nem bírálta felül, azonban 2007-ben és 2008ban egy-egy esetben a mediátor javaslata és az eredményes mediáció ellenére nem került sor az eljárás megszüntetésére, mert az ügyész felülbírálta a mediáció eredményességét.

A közúti baleset gondatlan okozása miatt induló eljárásban a munka nélküli és vagyontalan elkövető egyik rokonának okozott testi sérülést a balesettel. A sértett a mediáció során anyagi jellegủ jóvátételre nem tartott igényt. A mediátor a sértett jelzése alapján az eljárás megszüntetését javasolta az ügyésznek, a vádhatóság azonban a mediációt eredménytelennek, sikertelennek minősítette. Határozatának indokolásában kifejtette, hogy a megállapodás nem tartalmazott a sértett vonatkozásában jóvátételt igénylő eredményt. E határozattal szemben a védő és az elkövető panaszt jelentett be. A panaszt elbíráló megyei föügyészség azt állapította meg, hogy a mediáció eredményességének felülbírálata törvényes volt. A határozat indokolása szerint a gyanúsított az ügyész által elrendelt meghallgatáson ötvenezer forint jóvátétel megfizetését vállalta, illetve a sértett ezt kérte tőle, de a közvetítői eljárásban ennek megfizetésére nem került sor. A megyei föügyészség ezért a panaszt elutasította. ${ }^{32}$

Azokban az ügyekben, amelyekben a mediáció nem volt eredményes, a bíróság 2009-ben egy esetben próbára bocsátást és pártfogó felügyelet intézkedést alkalmazott, míg a többi esetben 2007-ben, 2008-ban, 2009-ben és 2010-ben pénzbüntetést szabott ki, 2010-ben a pénzbüntetés mellett jármüvezetéstöl eltiltást is kiszabott.

A bíróság által közvetítôi eljárásra utalt ügyekben a megállapodások teljesítési határideje nagyobb megoszlást mutat, mint az ügyészség által elrendelt közvetítői eljárások esetében. Kevésbé volt gyakori, hogy az elkövető már a mediációs ülésen teljesítette a megállapodásban foglaltakat. A megállapodások azonnali teljesítése 2007-ben 42,9, 2009-ben 50, és 2010-ben 60 százalékban volt jellemző. A többi esetben az elkövetők egy és hat hónap között tették jóvá a sérelmet. Az évek során a teljesítési határidő tartama egyre inkább kitolódott, és 2010-ben a felek már öt hónapos és hat hónapnál hoszszabb teljesítési határidővel is megkötötték a megállapodást. Az elkövető a megállapodást teljesítette, 2010-ben egy esetben az elkövető nem tudta teljesíteni a megállapodásban foglalt kötelezettségét.

32 Nyíregyházi Városi Ügyészség K.5234/2007.; Szabolcs-Szatmár-Bereg Megyei Főügyészség Nf.3732/2007. 
A maradandó fogyatékosságot előidéző közúti baleset okozása miatt induló ügyben a sértett fenntartotta a biztosítóval szembeni kárigényét, emellett ötszázezer forint fájdalomdíj megfizetését kérte a terhelttől. A terhelt részletfizetéssel vállalta a megállapodás szerinti fájdalomdíj megfizetését, azonban egyetlen részletet sem teljesített. ${ }^{33}$

A bíróság a közvetítői eljárás eredményességét egyik esetben sem bírálta felül. Azokban az esetekben, amelyben a közvetítői eljárás azért nem volt eredményes, mert nem került sor megállapodás megkötésére, vagy azt nem teljesítették, a bíróság az elkövetővel szemben pénzbüntetést szabott ki, és 2008-ban két, 2009-ben egy elkövetőt eltiltott a közúti jármüvezetéstöl.

\section{Az elkövetők elöélete és a mediáció hatása a reintegrációjukra}

A mediációban részt vevő elkövetők elöéletét vizsgálva megállapíthatjuk, hogy a terheltek többsége büntetlen előéletủ volt. Az ügyészség által közvetítői eljárásra utalt ügyekben csak 2009-ben fordult elő egyetlen bünismétlő terhelt. A bíróság által közvetítői eljárásra utalt ügyekben már nagyobb gyakorisággal fordultak elő a visszaesőnek nem minősülő bünismétlők. ${ }^{34}$

A mediáció folyamán többnyire feltárták a büncselekmény elkövetéséhez vezető okokat, és a mediáció elősegítette az elkövető reintegrációját. A mediációval érintett közlekedési büncselekmények miatt induló büntetöügyekben egyetlen esetben sem került sor a sértettnek okozott kár megtérülését garantáló zár alá vételre. A mediáció keretében azonban lehetőség nyílt arra, hogy az elkövető jóvátegye az okozott sérelmet. Az elkövető reintegrációját az eredményes mediáció minden esetben elösegítette. Azokban az esetekben, amelyekben a mediáció nem volt eredményes, gyakran került sor pénzbüntetés kiszabására, amely elvonhatta a vagyoni károk megtérítéséhez szükséges fedezetet, s így akadályozhatta az elkövető reintegrációját. Az eredményes közvetítői eljárás esetén az elkövető az eljárás megszüntetése után részt vehetett a közúti közlekedésben, míg az eredménytelen mediációs eljárások után a jogalkalmazó több esetben úgy ítélte meg, hogy a közlekedés biztonsága érdekében szükséges alkalmazni az elkövetővel szemben a jármüvezetéstől eltiltást.

33 Nyíregyházi Városi Bíróság B.169/2010.

34 2007-ben és 2008-ban egy-egy, 2009-ben és 2010-ben két-két esetben. 


\section{Összegzés}

A közvetítői eljárás gyakorlatát vizsgáló kutatásom az új jogintézmény bevezetése utáni négy év gyakorlatát ölelte fel. Bár jelen tanulmány kizárólag a közlekedési büntetöügyek mediációját elemezte, és a vizsgálat kevés ügyre terjedt ki, a tanulmányban ismertetett esetszámokból és a bemutatott jogalkalmazói döntések indokolásából egyértelmüvé vált, hogy a resztoratív igazságszolgáltatás paradigmáján alapuló mediáció szük keretek között kapott létjogosultságot a joggyakorlatban.

Ha a közlekedési mediáció tipikus elkövetöjét összevetjük a közlekedési konfliktusok tipikus terheltjével, azt látjuk, hogy a két személyi kör nem teljesen fedi egymást. A kriminológiai kutatások szerint az alacsonyabb iskolai végzettségüek felülreprezentáltak a közlekedési bünözésben, míg a kutatás megállapítása szerint a mediációt többnyire szakmával bírók és érettségizettek ügyeiben rendelték el. Ha az elkövetőnek nincs rendszeres jövedelme és vagyona, akkor nagyon kevés az esélye arra, hogy az ügye mediációra kerül. A kriminológiai vizsgálatok azt mutatják, hogy a közlekedési balesetek okozói büntetett előéletüek, a kutatás adatai szerint azonban a mediációt többnyire büntetlen elkövetők ügyeiben rendelték el. Mindez arra utal, hogy a jogalkalmazók a mediációt csak kivételesen, az elkövetői oldalon fennálló kedvező személyi feltételek esetén rendelték el. Hozzá kell tenni, hogy a mediációt még a közlekedési büncselekmények esetében is csupán a legenyhébben, az egyévi szabadságvesztéssel büntetendő esetekben rendelték el. Noha a közlekedési bủncselekmények között az ittas jármüvezetés a leggyakoribb, az ügyészi joggyakorlat ezt következetesen kizárta a mediációból. A bírói gyakorlat még kevés ügyben vizsgálta felül az ügyészi mérlegelési szempontokat, azonban egyértelműen tágabb elkövetői körben és többféle bủncselekménynél adott lehetőséget a felek konfliktusfeloldására. A mediációs ügyek számának folyamatos növekedése pedig mindenképpen bizakodásra ad okot. ${ }^{35}$

\footnotetext{
35 2011-ben már 5980, 2012-ben pedig 6410 ügyet utaltak közvetítői eljárásra. Áttekintés az Igazságügyi Hivatal egyes szakterületeinek feladat-ellátásáról. Közigazgatási és Igazságügyi Minisztérium Igazságügyi Szolgálata Pártfogó Felügyelői Igazgatóság. http://kih.gov.hu/mediacio
} 